\title{
CONSUMERS' PERCEPTION AND BEHAVIOR TOWARDS ECOSANOGENE PRODUCTS MADE BY GOAT MILK
}

\author{
Ramona Maria, IANCU \\ PhD Fellow, SOP HRD/159/1.5/S/133675 Project, ”Lucian Blaga” University of Sibiu, Sibiu, Romania, ramy11us@ yahoo.com
}

\begin{abstract}
This study was conducted in Sibiu, Romania to examine consumers 'ratings of healthy products made by goat milk and health issues. It has been also examine the sociodemographic factors and the relations between food safety and human welfare. This study is based on a questionnaire, interviewing a target group consists of 105 people. The purpose of this poll was to understand the consumer needs and how the quality of the brand influences purchasing choice. The instrument used for data processing was ANOVA Regression. The results can reveal that the selected model is valid for respondents who ticked test positive, $\mathrm{P}$-value $=1.31 \mathrm{E}-26<0.05$; for negative response (option "b), P-value $=1.27 \mathrm{E}-20<0.05$; for tests where the responses was with "do not know" is significantly stronger, too, $\mathrm{P}$-value $=1.61 \mathrm{E}-17<0.05$. The results presented in ANOVA Table validated the regression model which showed the interdependence between the three selected variables.
\end{abstract}

\section{INTRODUCTION}

In our days, consumers confront with one of the most important challenges - to protect and preserve their health. (Geeroms et all, 2008; Roosen et all, 2007, Chen, 2007) They have become concerned about the safety of the food manufacturers and suppliers. (Midmore, 2005)

Consumers are exposed to a large variety of information's, true or false one, regarding their health consequence of dairy consumption. (Pickett-Baker, 2008) Much of the advertising companies suggest that the dairy goat products have positive benefit for human health, but in fact, there are also messages which provide a challenge for the consumer to choose the products by its quality. (Grebitus et all, 2010; Tait et all, 2011) The current perception of more detailed information of the dairy goat products regarding the nutritional point of view and its hygiene has the potential to promote the consumption of these products. (Tita et. all, 2003; Carrigan et all, 2004)

The question of interest in this study is to find out if the product attributes play a role in consumer product choices and how the consumer decisions satisfy their needs, wants and demands.

\section{MATERIALS AND METHODS}

This study was made to understand consumer buying habits and preferences of sanogenous products obtain from goat milk and

SUMMARY OUTPUT also if the health messages have an impact of their consumption, an idea sustained also by Sun in 2008 This study is based on a questionnaire, interviewing a target group consists of 105 people around Sibiu, Romania. Making questionnaire led to questions about the: demographic data related to consumer, data regarding the ecosanogenous products, the goat dairy products, the welfare benefit of this kind of product over human health, which are the main criteria of purchasing the selected products.( D'Souza et all, 2007; Gracia et all, 2007) The questions in the questionnaire that were analyzed in this study have three possible answers, denoted as follows: variant a - "Yes", variant b - "No", variant c - "Do not know".

Recognition of consumption was conducted mainly at some outlets such as supermarkets, dairy products shops, interviewing the consumers directly through method "face to face". The purpose of this poll was to understand the consumer needs and how the quality of the brand influences purchasing choice. (Willer et all, 2012; Tonsor et all, 2013) The instrument used for data processing was ANOVA Regression.

\section{RESULTS AND DISCUSSION}

Statistical results on perception and consumer behavior towards ecosanogene products made of goat milk were made using regression functions of the software Excel.

\begin{tabular}{cc}
\hline \multicolumn{2}{c}{ Regression Statistics } \\
\hline Multiple R & 0,996577 \\
R Square & 0,993166 \\
Adjusted R & \\
Square & 0,992407
\end{tabular}




\begin{tabular}{cc} 
Standard Error & 1,404089 \\
Observations & 21 \\
\hline
\end{tabular}

ANOVA

\begin{tabular}{cccccc}
\hline & $d f$ & $S S$ & $M S$ & $F$ & Significance $F$ \\
\hline Regression & 2 & 5157,085 & 2578,543 & 1307,932 & $3,25 \mathrm{E}-20$ \\
Residual & 18 & 35,48636 & 1,971465 & & \\
Total & 20 & 5192,571 & & & \\
\hline
\end{tabular}

\begin{tabular}{ccccccc}
\hline & & Standard & & \multicolumn{2}{c}{ Upper } \\
& Coefficients & Error & $t$ Stat & P-value & Lower 95\% & $95 \%$ \\
\hline Intercept & 103,2135 & 0,97518 & 105,8405 & $1,31 \mathrm{E}-26$ & 101,1647 & 105,2623 \\
X Variable 1 & $-0,9914$ & 0,020203 & $-49,0727$ & $1,27 \mathrm{E}-20$ & $-1,03384$ & $-0,94896$ \\
X Variable 2 & $-1,01191$ & 0,030808 & $-32,8461$ & $1,61 \mathrm{E}-17$ & $-1,07663$ & $-0,94718$ \\
\hline
\end{tabular}

\section{RESIDUAL OUTPUT}

\begin{tabular}{cccc}
\hline Observation & Predicted $Y$ & Residuals & $\begin{array}{c}\text { Standard } \\
\text { Residuals }\end{array}$ \\
\hline 1 & 64,26177 & 1,738227 & 1,304941 \\
2 & 71,9674 & 2,032598 & 1,525934 \\
3 & 52,48801 & 2,511993 & 1,88583 \\
4 & 76,30213 & 0,697872 & 0,523914 \\
5 & 48,35835 & 1,64165 & 1,232437 \\
6 & 77,08846 & $-0,08846$ & $-0,06641$ \\
7 & 76,09706 & $-0,09706$ & $-0,07287$ \\
8 & 55,73587 & 0,264132 & 0,198292 \\
9 & 64,94557 & 0,05443 & 0,040862 \\
10 & 53,1718 & $-0,1718$ & $-0,12898$ \\
11 & 31,11491 & $-1,11491$ & $-0,837$ \\
12 & 52,94623 & 0,053771 & 0,040368 \\
13 & 25,72019 & $-0,72019$ & $-0,54067$ \\
14 & 70,12815 & $-1,12815$ & $-0,84694$ \\
15 & 77,10897 & $-0,10897$ & $-0,0818$ \\
16 & 50,71734 & 0,282655 & 0,212198 \\
17 & 39,16916 & $-0,16916$ & $-0,12699$ \\
18 & 60,27566 & $-0,27566$ & $-0,20695$ \\
19 & 70,976 & 0,023999 & 0,018017 \\
20 & 56,33057 & $-3,33057$ & $-2,50036$ \\
21 & 88,0964 & $-2,0964$ & $-1,57383$ \\
\hline
\end{tabular}

\begin{tabular}{cc}
\hline Percentile & $Y$ \\
\hline 2,380952 & 25 \\
7,142857 & 30 \\
11,90476 & 39 \\
16,66667 & 50 \\
21,42857 & 51 \\
26,19048 & 53 \\
30,95238 & 53 \\
35,71429 & 53 \\
40,47619 & 55 \\
45,2381 & 56 \\
50 & 60 \\
54,7619 & 65 \\
59,52381 & 66 \\
64,28571 & 69 \\
69,04762 & 71 \\
73,80952 & 74 \\
78,57143 & 76 \\
83,33333 & 77 \\
88,09524 & 77 \\
92,85714 & 77 \\
97,61905 & 86 \\
\hline
\end{tabular}




\section{Normal Probability Plot}

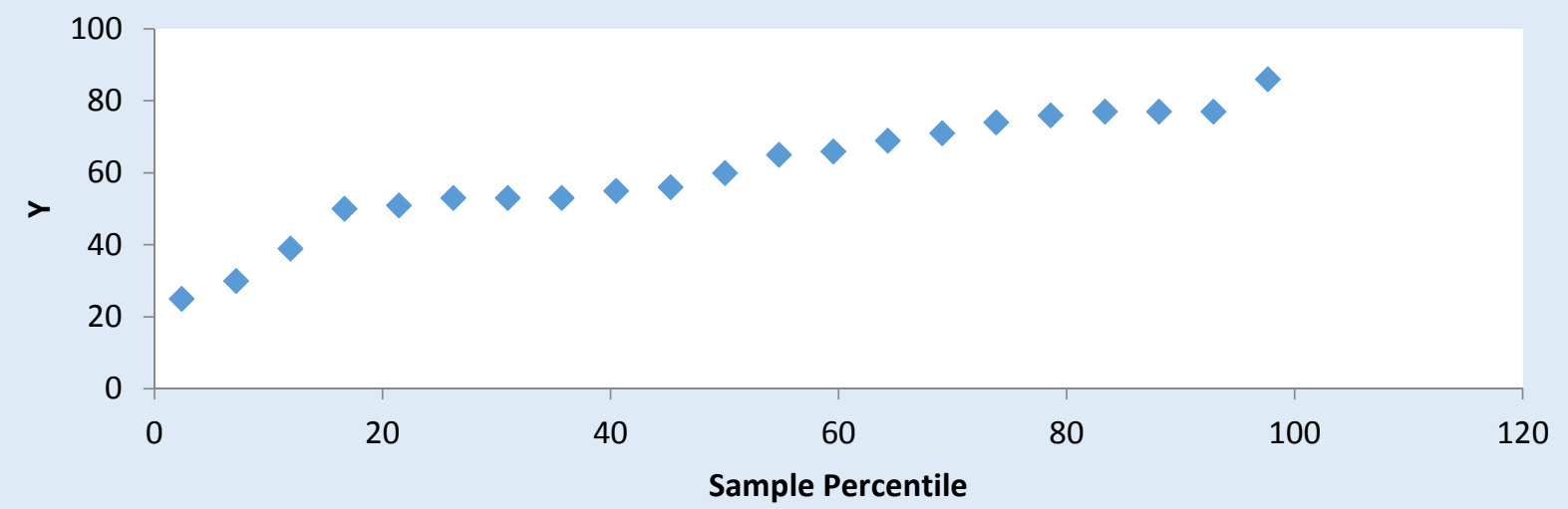

Figure 1. The regression line for the probable variant "a" answers

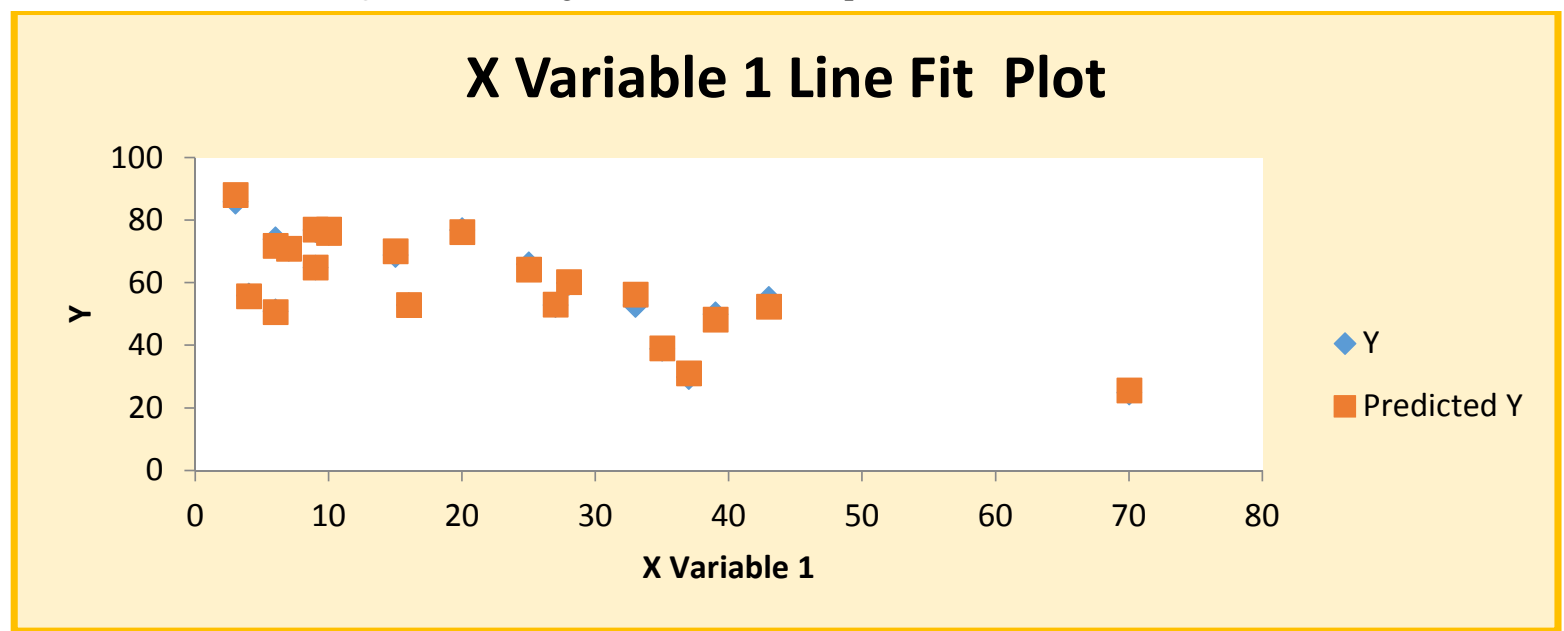

Figure 2. The regression line for the probable variant "b"" answers

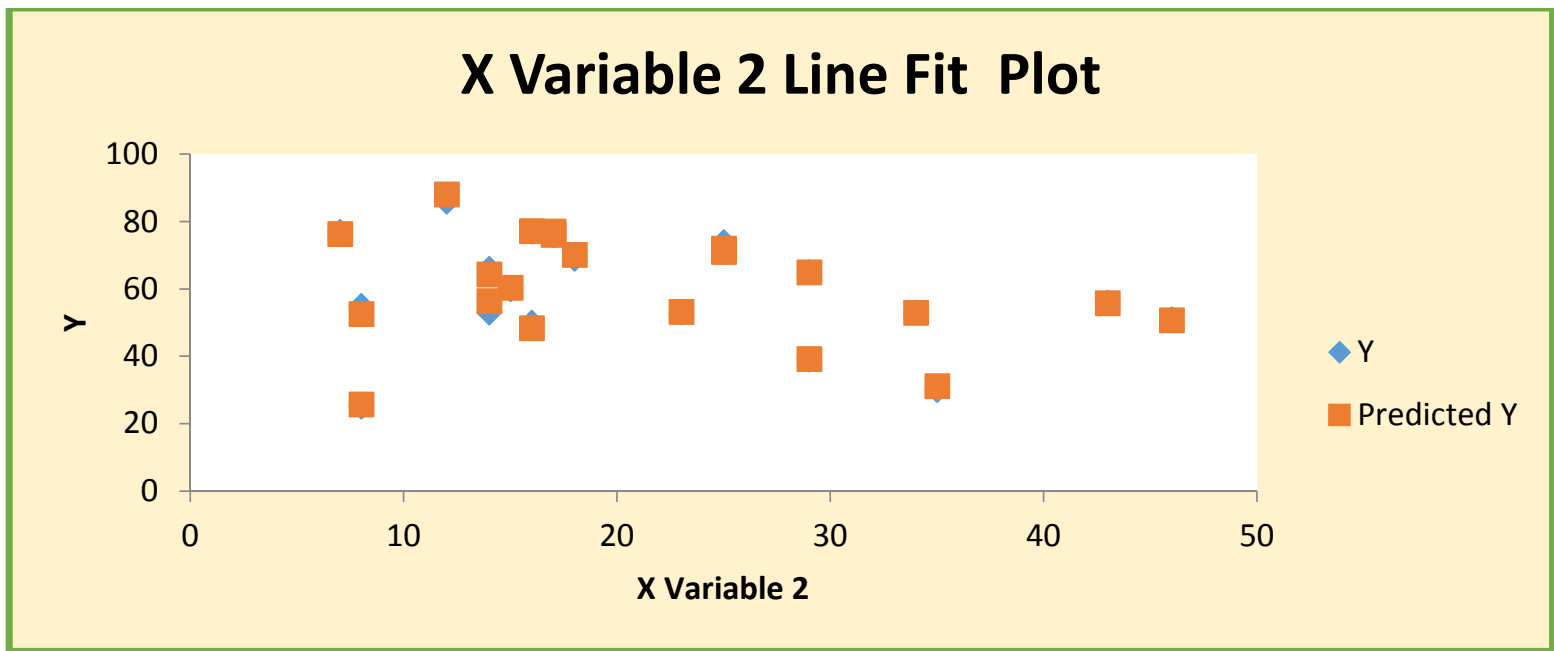

Figure 3. The regression line for the probable variant "c"” answers 


\section{Variable 1 Residual Plot}

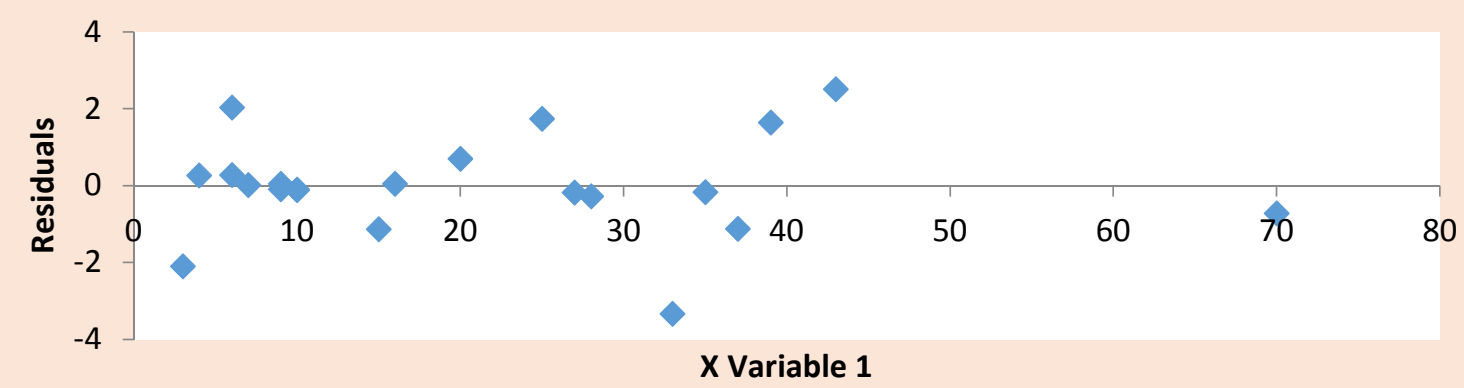

Figure 4. The regression line for the probable residual values of the " $b$ " variant

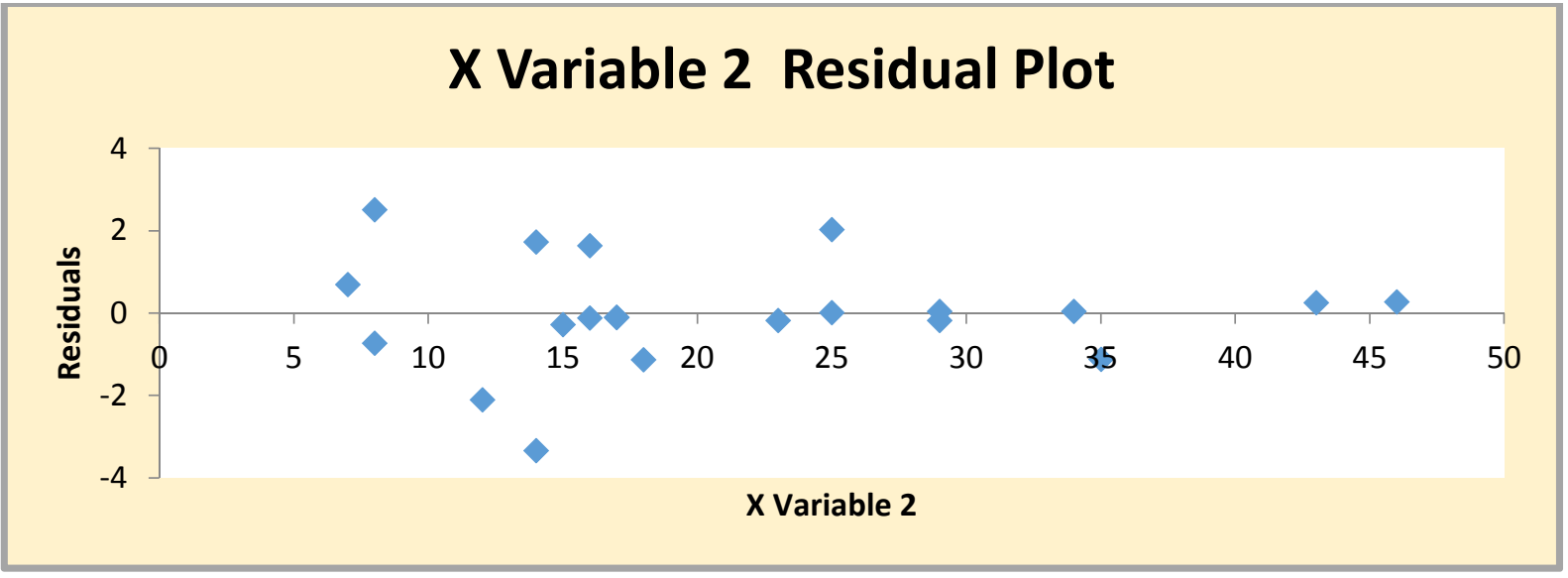

Figure 5. The regression line for the probable residual values of the "c" variant

\section{STATISTICAL RESULTS}

Table 1. Regression Statistics

\begin{tabular}{|c|c|c|}
\hline Multiple R & 0.996577 & $\mathrm{Ry}, \mathrm{x}=\sqrt{\frac{\sum_{\mathrm{i}=1}^{\mathrm{n}}\left(\hat{\mathrm{y}}_{\mathrm{i}}-\overline{\mathrm{y}}\right)^{2}}{\sum_{\mathrm{i}=1}^{\mathrm{n}}\left(\mathrm{y}_{\mathrm{i}}-\overline{\mathrm{y}}\right)^{2}}}=\sqrt{\frac{\sum_{\mathrm{i}=1}^{\mathrm{n}}\left(\mathrm{y}_{\mathrm{i}}-\hat{\mathrm{y}}_{\mathrm{i}}\right)^{2}}{\sum_{\mathrm{i}=1}^{\mathrm{n}}\left(\mathrm{y}_{\mathrm{i}}-\overline{\mathrm{y}}\right)^{2}}}$ \\
\hline R Square & 0.993166 & $\mathrm{R}^{2}=\frac{\Delta_{\mathrm{y} / \mathrm{x}}^{2}}{\Delta_{\mathrm{y}}^{2}}=1-\frac{\Delta_{\mathrm{e}}^{2}}{\Delta_{\mathrm{y}}^{2}\left(\hat{\mathrm{y}}_{\mathrm{i}}-\overline{\mathrm{y}}\right)^{2}}$ \\
\hline Adjusted R Square & 0.992407 & $\sum_{\mathrm{i}=1}^{\mathrm{n}}\left(\mathrm{y}_{\mathrm{i}}-\overline{\mathrm{y}}\right)^{2}$ \\
\hline Standard Error & 1.404089 & $\bar{R}^{2}=1-\frac{\Delta_{\mathrm{u}}^{2} / \mathrm{n}-\mathrm{k}-1}{\Delta_{\mathrm{y}}^{2} / \mathrm{n}-1}$ \\
\hline Observations & 21 & $\mathrm{~s}_{\mathrm{u}}=\sqrt{\frac{\Delta_{\mathrm{u}}^{2}}{\mathrm{n}-2}}=\sqrt{\frac{\sum_{\mathrm{i}=1}^{\mathrm{n}}\left(\mathrm{y}_{\mathrm{i}}-\hat{\mathrm{y}}_{\mathrm{i}}\right)^{2}}{\mathrm{n}-2}}$ \\
\hline
\end{tabular}

Table 2. ANOVA

\begin{tabular}{|c|c|c|c|c|c|}
\hline Source of variation & df & $\mathrm{SS}$ & $\mathrm{MS}=\mathrm{SS} / \mathrm{df}$ & $\mathrm{F}$ & Significance F \\
\hline Regression & $1(\mathrm{k})$ & 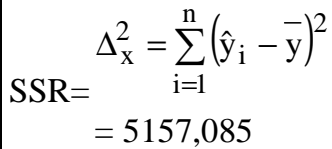 & $\begin{array}{l}\mathrm{s}_{\mathrm{x}}^{2}=\frac{\Delta_{\mathrm{x}}^{2}}{\mathrm{k}}= \\
2578,543\end{array}$ & $\begin{array}{c}\text { Test } \\
\mathrm{F}=1307,932 \\
\mathrm{~F}=s_{x}^{2} / s_{u}^{2}\end{array}$ & $3,35 \mathrm{E}-20<0,05$ \\
\hline
\end{tabular}




\begin{tabular}{|c|c|c|c|}
\hline Residual & $19(\mathrm{n}-\mathrm{k}-1)$ & $\begin{array}{c}\text { SSE }= \\
\Delta_{\mathrm{u}}^{2}=\sum_{\mathrm{i}=1}^{\mathrm{n}}\left(\mathrm{y}_{\mathrm{i}}-\hat{\mathrm{y}}_{\mathrm{i}}\right)^{2} \\
35,48636\end{array}=$ & $\mathrm{s}_{\mathrm{u}}^{2}=\frac{\Delta_{\mathrm{u}}^{2}}{\mathrm{n}-\mathrm{k}-1}=$ \\
\hline Total & $20(n-1)$ & $\begin{array}{c}\mathrm{SST}= \\
\Delta_{\mathrm{y}}^{2}=\sum_{\mathrm{i}=1}^{\mathrm{n}}\left(\mathrm{y}_{\mathrm{i}}-\overline{\mathrm{y}}\right)^{2} \\
5192,571 \\
\mathrm{SST}=\mathrm{SSR}+\mathrm{SSE}\end{array}$ & $\mathrm{s}_{\mathrm{y}}^{2}=\frac{\Delta_{\mathrm{y}}^{2}}{\mathrm{n}-1}$ \\
\hline
\end{tabular}

\begin{tabular}{|c|c|c|c|c|c|c|}
\hline Table 3. & Coefficients & $\begin{array}{l}\text { Standard } \\
\text { Error }\end{array}$ & t Stat & P-value & Lower 95\% & Upper 95\% \\
\hline & & & & & $\begin{array}{c}\text { The lower limit } \\
\text { of the } \\
\text { confidence } \\
\text { interval }\end{array}$ & $\begin{array}{l}\text { The higher limit } \\
\text { of the confidence } \\
\text { interval }\end{array}$ \\
\hline $\begin{array}{l}\text { Intercept } \\
\text { (free term) }\end{array}$ & $a_{0}=103,2135$ & $\begin{array}{c}s_{a_{0}} \\
=0,97518\end{array}$ & $t_{a_{0}}=105,8405$ & $\begin{array}{c}1,31 \mathrm{E}- \\
26<0,05\end{array}$ & 101,1647 & 105,2623 \\
\hline \multirow[t]{2}{*}{ Medium time } & $a_{1}=-0,9914$ & $\begin{array}{c}s_{a_{1}} \\
=0,020203\end{array}$ & $t_{a 1}=-49,0727$ & $\begin{array}{c}1,27 \mathrm{E}- \\
20<0,05\end{array}$ & $-1,03384$ & $-0,94896$ \\
\hline & $\mathrm{a}_{2}=-1,01191$ & $\begin{array}{c}\mathrm{S} \mathrm{a}_{2} \\
=0,030808\end{array}$ & $\mathrm{ta}_{2}=-32,8461$ & $\begin{array}{c}1,61 \mathrm{E}- \\
17<0,05\end{array}$ & $-1,07663$ & $-0,94718$ \\
\hline
\end{tabular}

\subsection{Interpretation of the SUMMARY OUTPUT Table results}

$\mathrm{R}=0.996577$ shows that between positive and negative responses from questionnaires concerning products ecosanogene there is a strong link.

$\mathrm{R} 2=0.993166$ shows that $99 \%$ of the variation in responses is explained by domain knowledge.

The standard deviation of errors su $=1.404089$ is different from zero so not all points are on the regression line. The number of questionnaires is 21 .

\subsection{Interpretation of the ANOVA Table results}

In order to validate the regression model, the test $\mathrm{F}$ is calculated using this table F. It is found that $F=1307.932$ and Significance $\mathrm{F}$ (materiality) is $3.35 \mathrm{E}-20<0.05$. Because the materiality level is less than 0.05 is considered valid and the selected model can be used to analyze the dependence of the three variables.

\subsection{Interpretation of the Table 3 results}

Intercept is the constant term, so the coefficient $\mathrm{a} 0=103.2135$. $\mathrm{Ta} 0=105.8405$, is a significant factor because the $\mathrm{P}$-value $=$ $1.31 \mathrm{E}-26<0.05$. This shows that most respondents answered positively the questionnaire. The lower limit of the confidence interval is 101.1647 and the upper, 105.2623. This shows that the parameter of collectivity is positive.

The coefficient a1 $=-0.9914$ which shows that in a future questionnaires, the number of respondents who ticked the answer $b$ will be about 0 ; ta $1=-49.0727$. The materiality level $\mathrm{P}$-value $=1.27 \mathrm{E}-20<0.05$ indicates that the coefficient is highly significant. The confidence interval for this parameter is 1.03384 and -0.94896 .

The coefficient a2 $=-1.01191$ which shows that in a future questionnaires, the number of respondents who ticked the answer $\mathrm{c}$ will be about 0 ; ta2 $=-32.8461$; the materiality level $\mathrm{P}$ value $=1.61 \mathrm{E}-17<0.05$ indicates that the coefficient is highly significant. The confidence interval for this parameter is 1.07663 and -0.94718 .

\section{CONCLUSIONS}

The results can reveal that the selected model is valid for respondents who ticked test positive, $\mathrm{P}$-value $=1.31 \mathrm{E}-26<0.05$. Respondents which responded with option $b$ (negative) had a significantly stronger coefficient, in this statistical analysis, where P-value $=1.27 \mathrm{E}-20<0.05$. The coefficient selected for tests where the responses was with "do not know" is significantly stronger, too; where P-value $=1.61 \mathrm{E}-17<0.05$. The results presented in ANOVA Table validated the regression model which showed the interdependence between the three selected variables.

During our study, men expressed less concern than did women about the importance of healthy product consumption. Another important issue is that highly educated people, especially people over 30 years, expressed most concern about this.

The differences pointed out during the investigation suggest that the influence of society and consumer perception may have a significant influence on the consumption of healthy products from goat milk. 
This study maintains that population assessment in food issues may be relatively independent of differences in survey questions.

\section{ACKNOWLEDGEMENTS}

This paper is supported by the Sectoral Operational Programme Human Resources Development (SOP HRD), financed from the European Social Fund and by the Romanian Government under the contract number POSDRU/159/1.5/S/133675.

\section{REFERENCES}

1. Carrigan, M.; Szmigin, I.; and Wright, J., Shopping for a better world? An interpretive study of the potential for ethical consumption within the older market. The Journal of Consumer Marketing, 21(6), 2004, 401-417.

2. Chen, M.F. (2007), Consumer attitudes and purchase intentions in relation to organic foods in Taiwan: moderating effects of food-related personality traits, Food Quality and Preference, 18 (7), 1008-21.

3. D'Souza, C, Taghian, M. And Khosla, R., Examination of environmental beliefs and its impact on the influence of price, quality and demographic characteristics with respect to green purchase intention. Journal of Targeting, Measurement and Analysis for Marketing, 15(2), 2007, 6978.

4. Geeroms N., Verbeke W., Van Kenhove P. (2008). Consumers' health-related motive orientations and ready meal consumption behaviour. Appetite, 51, 704-712.

5. Gracia, A. \& de Magistris, T. (2007), Organic food product purchase behaviour: a pilot study for urban consumers in the South of Italy, Spanish Journal of Agricultural Research, 5 (4), 439-51.

6. Grebitus, C., Colson, G., Menapace, L., and Bruhn, M: (2010). Who cares about food origin? A comparison of hypothetical survey responses and actual shopping behavior. Paper presented at Annual Meeting, of Agricultural \& Applied Economics Association, Denver,
USA,

available

at:

http://ageconsearch.umn.edu/handle/61344

7. Midmore P. et al (2005). Consumer attitudes to quality and safety of low input and organic food: a Review. QLIF (Quality Low Input Food) report. Aberystwyth: School of Management and Business (The University of Wales, UK), 2005, 67 p.

8. Pickett-Baker, J., \& Ozaki, R., Pro-environmental products: marketing influence on consumer purchase decision. Journal of Consumer Marketing, 25 (5), 2008, 281-293. Publications, London.

9. Roosen, J., Marette, S., Blanchemanche, S., \& Verger, P. (2007). The effect of product health information on liking and choice. Food Quality and Preference, 18, 759-770.

10. Sun, Y.-H.C. (2008). Health concern, food choice motives, and attitudes toward healthy eating: the mediating role of food choice motives. Appetite 10.1016/j.appet.2007.

11. Tait, P.R., Miller, S., Abell, W., Kaye-Blake, W., Guenther, M. and Saunders, C.M. (2011). Consumer attitudes towards sustainability attributes on food labels. Paper presented at 55 th Conference of Australian Agricultural and Resource Economics Society, Melbourne, Australia. available at: http://ageconsearch.umn.edu/handle/108953

12. Tiţa, M., Tiţa, O. \& Oprean L. (2003). The additives behavior in the milk industry and the role of the experimental results in the students' education, 2nd Balkan Region Conference on Engineering Education, Bridges for Co-operation in Engineering Education, Sibiu, Romania, 234-236.

13. Tonsor, G.T. (2011). Consumer inferences of food safety and quality. European Review of Agricultural Economics, 38 (2): 213-235.

14. Willer, Helga and Kilcher, Lukas (Eds.) (2012) The World of Organic Agriculture - Statistics and Emerging Trends 2012. Research Institute of Organic Agriculture (FiBL), Frick, and International Federation of Organic Agriculture Movements (IFOAM), Bonn V 2.0 10/02/2012 